\title{
Marxist Theory in Critical Transitions: The Democratiza- tion of the Media in Post-Neoliberal Argentina
}

\author{
Pablo Castagno
}

\author{
Universidad Nacional de La Matanza, San Justo, Argentina, pcastagno@unlam.edu.ar
}

\begin{abstract}
This article contends that for socialist emancipation to advance it is crucial to investigate how political cadres conceal, regulate or displace the demands of citizens and workers in the context of the calamitous effects of global capitalism. Analyzing the constitutive relationship between politics and the media is an essential component in researching those practices of state ideological production. Specifically looking into the transformation of media policy in the case of Argentina, this article problematizes the different political forms through which the state has cloaked its fundamental contradiction: alleged representation of the general interests of citizens, when explored in critical depth, reveals the state's actual adjustment to a process of capitalist transnationalization that increases irrationality, social inequality and misery. Through this lens, the article emphasizes the value of Marxist dialectic method and theory in imagining a true democratic future.
\end{abstract}

Keywords: Critical Political Economy, Global Crisis, Hegemony, Media Policy, Marxist Political Theory, Neoliberalism, Populism, Kirchnerismo

\section{Introduction}

Examining Argentina, my purpose is to explore how state and political cadres endeavor to contain the social tensions spanning from states' essential contradiction as institutions that claim to represent the general and national interests of citizens while reproducing the transnational class domination in which global capitalism is based. ${ }^{1}$ Specifically, I argue the media constitutes a key field of state ideological regulation and political struggle. By ideology I mean the goal of dominant political groups and classes to disseminate their own ideas throughout a society such that these ideas become dominant (Marx and Engels 1998/1846), cohering social formation in a process of cultural and political leadership (Gramsci 2000, 200-210) and absorbing or articulating in this way the discourses of other groups and classes in order to nullify their potential antagonism (Laclau 1978, 187-189). Further, I understand those symbolic practices as having an objective role in hiding the real nature of society, built as it is on antagonisms (Marx and Engels 1998/1848; Marx 1978/1867, 319-328; Horkheimer 1989/1932, 55). I use regulation here to connote the institutionalization of ideologies throughout the state in the form of legal instruments, state policies, discursive practices, and so on.

Conceptualizing ideological regulation in this way, I engage with views maintaining that Karl Marx's work and subsequent interpretations of Marxist thought facilitate analysis of the media as an unfixed object integrated into the general political-economic process through which structural contradictions in capitalism are played out, reproduced, contested or transformed (Murdock and Golding 1973; Garnham 1979; Wayne 2003; Artz, Macek and Cloud 2006; McChesney 2007; Mosco 2010; Fuchs 2011). These works' shared critical theoretical and methodological approach situates the study of the media within the totality of the social relationships constituting a given historical moment. In concrete terms, my task is to investigate how political cadres respond to corporations' pressures to increase profits, aim to legitimate the state apparatus, and cope with the democratic demands of citizens and workers in the context of capitalist crises and political turmoil. ${ }^{2}$ Following Marx, I understand capital crises to be phases of rupture in the realization of profits through the exchange of commodities (Marx 1978, 433-465). These crises include different episodes, such as the 2008 financial crisis, and are characterized by attempts from the dominant class to ensure capitalist profits.

At the empirical level, Argentina constitutes an interesting and relevant political field of analysis due to its profound capitalist slump in 2001-2002, its previous crises and its periodic shifts in state ideology. I argue that the contemporary history of media transformation in Argentina has three political epicenters: the implementation of new media legislation (Law 22,285, 1980) by the military junta dictatorship (1976$1983),{ }^{3}$ the modifications that the democratic and neoliberal government of Carlos Menem (1989-1999)

\footnotetext{
${ }^{1}$ Following Manuel Castells' work, by global capitalism I mean an economy whose core components have the potential to work as a unit in real time and on a planetary scale $(2000,105)$.

${ }^{2}$ Following Nicos Poulantzas, I understand that political cadres constitute a social category, not a class (1969, 72). Their function is to reproduce the state, which is also essential for the dominant economic class and capitalism as a whole.

${ }^{3}$ The Executive Power was in charge of three chief commanders from the army, the navy and the air force.
} 
introduced to that legislation, and the approval of a law on media democratization by Cristina Fernández de Kirchner's government (2007-present) in 2009. In terms of political orientation, the current government represents a continuation of Néstor Kirchner's period (2003-2007). Néstor Kirchner was the president elected following the devastating financial collapse of the neoliberal project in 2001-2002. This slump pushed forty percent of the total population into unemployment and sub-employment and half of the total population under the line of poverty (Oficina de la CEPAL 2010; Lozano 2005, 4), ${ }^{4}$ deeply eroding state legitimacy. Both Menem and Kirchner belonged to the Partido Peronista, a former nationalpopulist party that emerged in the 1940s. Yet while Menem implemented thorough neoliberal reforms targeted at assuring the state's link to global capitalism (Castagno 2010, 119-176), so-called Kirchnerismo has constituted a complex case of state continuity and change.

Exploring these periods of contemporary history, my central question is how media policy is related to the various state projects aimed at resolving the capitalist collapses, and responding to the political contestation by workers and citizens in the mid-1970s, the late 1980s and 2001-2002. Drawing from Marxist theory on political-economic crises and Marxist method, my historical approach to this research question seeks to explain the contradictory relationships among the state, the media and citizens. My general objective is to determine and explain the ideological variations in media policy across the various political regimes and governments, and my specific objective is to analyze Cristina Fernández de Kirchner's reform of class and ideological relationships within the audiovisual media system. For this research, my qualitative investigation examines media legislation on broadcasting and audiovisual communication services as part of the various state political economy projects. I define media legislation as a field of power in which citizens, political cadres and the dominant economic class struggle to establish state parameters according to which media resources are distributed and public communication delimited. ${ }^{5}$ This field simultaneously contains, reflects and constitutes the social totality in which it is immersed. My principal argument is that Kirchnerismo has perpetuated a bourgeois state project of capitalist transnationalization, initially enforced by the military dictatorships between 1955 and 1983 and later pushed forward by Menem's government (Portantiero 1974, 1977; Castagno 2010) but that, as the project's current iteration, Kirchnerismo has relied on state populist forms of media-ideological regulation different from the previous nationalist-authoritarian and neoliberal ideological regulations. Focusing on media policy, I seek to critically highlight the rift between social reality and state claims.

\subsection{Situating the Media: Capitalist Crises and State Transformations}

Marx's work is crucial for thinking realistically about the state and the capitalist system. Distinct from other perspectives in the social sciences and political economy, Marx's historical-materialist method analyzes the contradictions and class conflicts that constitute the historical process under capitalism. Marx demonstrates that modern history is shaped by fundamental antagonisms between capital and wage labor, and between the socio-economic dynamics and the political life of societies. For Marx, apprehending and representing the concrete reality is part of the revolutionary practice of building an equal and free society (Lukács 2000/1923, 3). His research method is grounded in critical theoretical approaches, and is aimed both at grasping the distance between social reality and current social values and overcoming dialectically the distinction between social research and practical-critical activity (Marx 1998/1845, 572-574).

Marx observes that capitalism is characterized by cycles of capital accumulation and crises. As noted above, by crises he means phases of interruption in the process of reproduction of capital (Marx 1978, 446). He demonstrates that this reproduction is based on firms' exploitation of wage labor for the production of commodities (exchange value) to be exchanged in the market for sums of money: capitalism pays the labor class only the socially necessary amount of money for its reproduction and obtains its force for the production of surplus-value, which takes a commodity-form. According to Marx, capital is the accumulation of exchange value and requires the constant circulation of capital and commodities $(1978 / 1867,302-336)$. For any enterprise to obtain profits, capital accumulation is necessary to guarantee an expansion of the workforce, employ more technology in production, increase the relative exploitation of labor per unit of time and produce more and cheaper commodities to compete on the market. Marx explains that capitalism in consequence needs to balance capital investment and the means of consumption, or consumer commodities (Marx 1992/1885). He highlights that crises occur due to the propensity of the capitalist system "to exploit the maximum amount of labor without any consideration for the actual limits of the market or the needs backed by the ability to pay; and this is carried out through the continuous expansion of reproduction and accumulation, and therefore constant conversion of revenue into capital" (Marx 1978, 465). He also notes that the bourgeoisie - the dominant economic class - endeavors to resolve crises through the enforced destruction of a mass of productive forces, the con-

\footnotetext{
${ }^{4}$ Sub-employment refers to workers that work less than 35 hours per week although they wish to work more hours.

${ }^{5}$ I thus analyze thematic issues such as state regulation of media ownership, administration of broadcast licenses, capital accumulation in the media sector, and democratization of the media.
} 
quest of new markets and the more thorough exploitation of old ones (Marx and Engels 1978/1848, 478).

Applying this theoretical perspective we can discern two central turning points in contemporary global capitalism. The first is located during the early 1970s. As David Harvey and other authors demonstrate, it was in this period that the cycle of capital accumulation that spanning from the end of World War II encountered serious difficulties in the United States and elsewhere (Harvey 1991, 140-147). Political cadres and the transnational bourgeoisie responded to that crisis in capitalist profitability by dismantling mechanisms of state economic interventionism and establishing a neoliberal agenda (Smith 1997; Duménil and Lévy 2004). Since then we have seen how state cadres privatized state-owned companies, eliminated labor rights, contributed to the displacement of commodity production to cheaper regions, liberalized international trade, eliminated rules restricting the concentration and centralization of capital, warranted the independence of finance capital from the state, attempted to resolve the crisis in industrial profitability by intensifying the production of financial commodities - for instance, through the privatization of state pension systems - and expanded the commodification of culture by stimulating the production of new media, tourist, leisure and sports commodities. ${ }^{6}$ Today it is evident that this neoliberal project has run up against obstacles and a global capitalist crisis is emerging. This is revealed in the stagnation of Gross Domestic Product (GDP) in the European Union and the United States during the last five years. Indeed, before this rise of the current crisis in the North, the neoliberal project had collapsed in many Southern states.

My contention is that media research needs to be situated in that historical process. To put it in Gramscian terms, we need to investigate how contradictions in the economic structure have repercussions on political, ideological and cultural formations (Gramsci 2000, 427). At the same time, we must examine how political and cultural practices transform the economic structure - i.e. the manner by which dialectically active cultural, political and economic processes constitute and transform one another. For example, inspired by Marx's study of the processes of revolution and counter-revolution altering the state and private property (1978/1852), Antonio Gramsci employs the category of organic crisis for explaining the periods of disturbance in commodity exchange and state formation. For Gramsci, one of the principal signs of an organic crisis is when the traditional forms of political representation are no longer recognized as adequate by the dominant economic class, and are resisted by the subaltern classes $(2000,217-221)$. In these historical situations, the subaltern classes pass to a state of political activity, ruling class's hegemony is delegitimized, the rule of the ruling class is only sustained by coercion, the economy is paralyzed, and a crisis of the state as a whole emerges (Gramsci 2000, 218).

In that light, I contend the media is one of the state spheres in which political groups and classes establish new ideological articulations, alliances and hegemonies to cope with an organic crisis. In Gramsci's terms, hegemony refers to the political, cultural and moral directions consented to by citizens and workers $(2000,194)$. The importance of this function of the media increases concurrently as the organic crisis erodes the contracts among institutional actors (governments, trade unions, business associations) and the relationship of citizens to political parties. Further, since the media is a cardinal medium smoothing the general process of commodification and capital accumulation (Mosco 2010, 130; Fuchs 2009; 2011, 135-160), the media sphere is an essential space in which the dominant economic class can intensify commodity exchange after any capitalist collapse. Briefly, considering the media from a Marxist standpoint I examine the class and political struggles to reproduce capital accumulation and state legitimacy, or to create alternative media, political and economic systems. This kind of investigation is essential for a dialectic view of the state as an unstable formation that needs both to reproduce the domination of the transnational bourgeoisie and of listening citizens. In other words, the analysis of media policy allows for the application of two Marxist views to the state (Held 1991, 144): the state as the organ of the ruling class (Marx and Engels 1978/1848, 475), and the state as an institution that has some relative autonomy despite its reproduction of dominant bourgeois interests (Marx 1978/1852; Poulantzas 1969). While Marxist studies have tended to stress the capitalist reproductive role of the media as an institution of ideological control (Althusser 2001/1970, 95), it is also important to grasp the state's imbalance between reproduction and hegemony.

\section{Ideological Instability in Argentine Media Policy}

Cristina Fernández de Kirchner's media reform represents part of the progressive political debate around the collapse of the neoliberal project in 2001-2002, when the state defaulted on its government bonds and sharply devalued its currency after three years of economic recession. This discussion centers on the nature of the state established by the neoliberal government of Carlos Menem (1989-1999) and the military dictatorship (1976-1983). Kirchnerismo proponents' argument is that the military junta introduced the neoliberal shift and Menem deepened it. This is a convincing interpretation with which 127).

${ }^{6}$ In Marxist terms commodification refers to the transformation of use-values into exchange products (Mosco 2010, 
political cadres can appeal to the citizenry because the dictatorship implemented a structural capitalist adjustment program that repressed workers and citizens. The military junta aimed to eliminate the dissent of citizens to the state and to forcibly subjugate workers through state terrorism and economic policies. The regime kidnapped, murdered and "disappeared" thousands of workers, students and political activists (CONADEP 2003, 296) ${ }^{7}$ reduced wages; liberalized foreign trade for corporations to import technology, boost so-called labor productivity and increase exports; and interwove the economy with Northern finance capital - raising state debts and absorbing corporations' debts. ${ }^{8}$

Yet what is missed in the narrative of Kirchnerismo is that the state had been pursuing its policy of subduing labor and assuring the state's link to Northern capitalism since the armed forces' coup d'état against the democratic government of Juan Domingo Perón in 1955, who had implemented a project of national capitalism (Portantiero 1974; 1977; Castagno 2010). ${ }^{9}$ Following a cycle of military dictatorships (1955-1958, 1966-1973), the military junta intensified both state coercion and the economy's interdependence with Northern capitalism. This assault came after a period in which workers were seriously counteracting the hegemony of the state and capital through labor organization on the shop floor, in new trade unions, and through general strikes and political mobilization (Werner and Aguirre 2009, 167-260). This organic crisis in state authority coincided with a deepening of the economic recession and a hyperinflationary crisis in $1975,{ }^{10}$ along with the pressures from advanced capitalist countries - what I term Northern capitalism - to displace capital to new geographical zones (Harvey 1991, 185).

I posit that adopting a longer historical perspective reveals that what varies in the interlocking of the Argentine state with Northern capitalism are the regulatory frameworks, coercive mechanisms and ideological forms through which the state and political cadres demand the compliance of citizens to the state and capital. Continuity in the state strategy of capitalist transnationalization is seen in its promotion of foreign investments, its consolidation of the export-led dimension of the economy, its facilities for multinational corporations to export capital and its periodic adjustments to discipline so-called labor productivity according to global standards. The various regulatory and ideological tactics are observed clearly in the establishment of either dictatorial or democratic regimes, and in the political cadres' appropriation of center-left or popular-democratic, Peronistas, ideologies. Thus, in terms of ideological tactics, the dictatorships implanted repressive nationalism to counter the demands of workers, trade unions, the Partido Peronista and national-leftist parties. They accused resistant Peronist workers, national-leftist sectors of the Partido Peronista and armed national-leftist groups of demagogy, corruption and international terrorism under the influence of international socialism. The military junta's Law 22,285 on broadcasting (1980), synthesizing the so-called national security doctrine, is a case in point.

For example, the military junta set the regulation of broadcasting under the control of the Executive Power (the chief commanders of the Junta). It also established that representatives from the army, the navy, the air force, the Secretary of Public Information, the State Secretary of Communication, along with two representatives of the private media associations, must administer the institution regulating the media (Comité Federal de Radiodifusión, COMFER). ${ }^{11}$ Moreover, the law 22,285 demanded that media content had to be in accordance with the institutions of the "Republic," the national tradition and the moral norms of Christianity. The law required broadcasters to "disseminate information and collaborate [with the Executive] to satisfy the needs of national security." ${ }^{\prime 2}$ State and commercial broadcasters were requested to avoid content that would diminish patriotism and to eliminate content that would exalt ways of life or ideologies contradictory with the moral, social and political norms of the country (art. 5 and decree 286/81). This ideological coercion included the ban of not-for-profit media. ${ }^{13}$ The de facto legislation on broadcasting was thus a condensation of nationalist authoritarianism and commercial media's

\footnotetext{
${ }^{7}$ National Commission on the Disappearance of People. The democratic government of Raúl Alfonsín established CONADEP

${ }^{8}$ For non-Marxist approaches that consider these facts see, for example, Calcagno (1988) and Rapoport (2003). The official state narrative today tends basically to highlight the military junta's disappearance of citizens and the military junta's corruption in indebting the state. In other words, it does not situate those crimes within the capitalist conditions of the state.

${ }^{9}$ For instance, while by 1957,64 of the top 100 companies were national corporations and the rest Northern corporations, by 1971, 72 of the top 100 companies were foreign multinational corporations and the rest national corporations, usually linked the latter (Sourrouille 1985, 51). As Juan Carlos Portantiero critically puts it, "Two basic alternatives were open [in the mid 1950s]. One was to force the course of development directed until then by Peronism toward a model of development based on a solid alliance between the state and national capital. The other was to create conditions for a new stage of capitalist development by means of the implementation of a politics that, emphasizing dependence, would be able to guarantee the control of the economy to the most concentrated sectors" (Portantiero 1974, 102). For non-Marxists views on capitalist transnationalization during the 1960s see Juan Vital Sourrouille (1985) and Guillermo O'Donnell (1988).

${ }^{10}$ By 1975 the symptoms of the capitalist crisis were evident in Argentina: annual inflation climbed to 444 percent, the GDP and investments stagnated, fiscal deficit skyrocketed to 16 percent, foreign debt rose, foreign trade deteriorated and trade unions finally rejected a drastic currency devaluation and wage freeze in 1975 (Rapoport 2003, 651-694).

${ }_{11}^{11}$ Federal Broadcasting Committee.

${ }^{12}$ Art. 7.

${ }^{13}$ Art. 45
} 
interests. However, the dictatorship's achievement of its desire for capitalist growth through repressive nationalism was contradictory.

State authoritarianism supported capitalism by suppressing labor and cultural dissent but at the same time set barriers to capital circulation and accumulation. For instance, besides the nationalist constraints, the media legislation restricted the production of media commodities by establishing moral limits on the broadcasting of content. It required broadcasters to abstain from delivering "sordid, corruptive or repulsive news," "obscene gestures," "sexual perversions," "the triumph of evil" or "public commotion." 14 Law 22,285 demanded media companies to broadcast mainly national content, established Spanish as the only media language, requested the COMFER to authorize the information circulated by FM radios, and forbade the formation of private broadcasting networks. ${ }^{15}$ It also prohibited the broadcasting of game shows, media ratings and the use of telephone calls in broadcasting content. ${ }^{16}$ These regulations restricted capital accumulation not because corporations could not commodify nationalist or moral products, but because they limited the range of use-values that corporations could commodify.

Such legislation also limited capital accumulation by restraining capital centralization, concentration and commercialization. ${ }^{17}$ It stipulated that commercial broadcasters could not own press companies, administer public services or manage more than four broadcasting licenses. ${ }^{18}$ It also impeded broadcasters from becoming subsidiaries of foreign corporations, selling licenses and commercializing shares for the first five years in operation. ${ }^{19}$ On commercialization - that is, on the establishment of relationships between audiences and advertisers (Mosco 2010, 132) - Law 22,285 forbade advertising during programs, restricted advertising production to national firms and prohibited advertisements offensive to "the integrity of the family and Christian morality." ${ }^{20}$ In short, while the military junta aimed to resolve the organic crisis of the 1970s and consolidate transnational capitalism, at least in the media market it restrained capital accumulation via the form of moral coercion and cultural control it assumed. In this sense, it is illustrative that the dictatorship controlled the state-owned television channels, and privatized the television channels Canal 9 and Canal 2 just before leaving power in hands of the democratic government of Raúl Alfonsín. ${ }^{21}$

After the impasse of Alfonsín's government - in which neither the dominant economic class nor workers could resolve the long-lasting stagnation - the democratic government of Carlos Menem (1989-1999) removed the dictatorship's restrictions on the media market. Menem promised workers that he would end the crisis and increase social equality, yet he established wide-ranging neoliberal reforms to favor capital. In the media field, Menem eliminated former moral prescriptions and authorized companies to broadcast game shows, content in other languages, advertisements during programs, telephone calls integral to the shows, ${ }^{22}$ or brands' catalogues. ${ }^{23}$ His new legislation first permitted the state-owned television channel to broadcast advertising and then increased advertising time, ${ }^{24}$ while also authorizing broadcasters to deliver ratings statistics - a procedure communicating the idea that within society specific audiences exist for advertisers to entice. ${ }^{25}$ Those regulatory changes increased the commodification and commercialization of media content, allowing the emergence of programs previously unimaginable: talk shows, political scandals, news on crimes, cheap humor programs with hosts promoting a battery of brands, all kind of contests and porn cable television channels. In short, Menem's media policy rendered evident what Marx highlights: capitalism is indifferent to the actual content of the commodity. In Marx's words, "Could commodities themselves speak, they would say: Our use-value may be a thing that interests men. It is not part of us as objects. What, however, does belong to us as objects, is our value. Our natural intercourse as commodities proves it. In the eyes of each other we are nothing but exchangevalues" (1978/1867, 328).

\footnotetext{
${ }^{14}$ Law 22,285 (art. 18) and decree 286/81 (art. 1). On the dictatorship's repression of cultural life see also Guillermo O'Donnell (1984).

${ }^{15}$ Art. $15,19,58$ and 68 . Decree 286/81. Forty percent of the total content broadcast had to be national content.

${ }^{16}$ Art. 24 and 25 .

${ }^{17}$ In Marxist terms, concentration refers to the accumulation of capital vis-à-vis the labor process (capital concentrates all the means of production in many firms), and centralization refers to the command and ownership of different economic sectors or sub-sectors by a firm or capital (Shaikh 1991, 76-77).

${ }^{18}$ Art. 43.

${ }^{19}$ Art. 45 and 46

${ }^{20}$ Art. 23.

${ }^{21}$ The dictatorship returned those television channels to their original owners. In 1974 Perón's government had nationalized them.

${ }^{22}$ The most successful show of the 1990s (Hola Susana) broadcast game shows where the audience had to call the show to participate.

${ }^{23}$ Decrees 1062/98, 1005/99, and 1065/99.

${ }^{24}$ Decrees $1652 / 96$ and $1005 / 99$.

${ }^{25}$ Decree 1062/98. The constitution of audiences is fundamental for the process of commodification. As Dallas Smythe observes (1977), the capitalist media needs to produce audiences for advertisers. For a critical review see Vicent Mosco $(2010,136-138)$
} 
Menem's government also nourished capitalism by altering rules on media ownership. It privatized the state-owned television channels Canal 13 and Canal 11, authorized press and telephone companies to own television and cable channels, ${ }^{26}$ expanded from four to twenty four the number of licenses that media corporations could administer, ${ }^{27}$ removed time limits on selling media corporations' shares, ${ }^{28}$ allowed the formation of broadcasting networks and removed restrictions on the transference of licenses. ${ }^{29}$ In addition, Menem's legislation on foreign investments pampered the movement of capital in and out of the media market. The law 21,382 (1993) and fifty-three new treaties on foreign investments — which have pre-eminence over the national laws ${ }^{30}$ - established the state's equal treatment of foreign and national capital as well as authorized international investors to repatriate profits and capital without barriers. Menem's neoliberal policy thus facilitated media centralization and concentration, and on a transnational basis no less. For example, the press company Grupo Clarín became the largest multimedia group: ${ }^{31}$ in particular, its company Cablevisión bought cable television networks throughout the country, administering about 260 cable television licenses. ${ }^{32}$ At the same time, new global capital flowed into the market: for instance, Telefónica International - a company that emerged out of the privatization process in Spain - acquired Canal 11 and went on to administer nine other television licenses, Liberty Media Corporation bought a quarter of the shares of Cablevisión and Goldman Sachs purchased eighteen percent of the shares of Grupo Clarín (CEPAL 2002, 97).

Thus we see that Menem's media policy was integrated to his neoliberal state machinery. This policy implemented new pro-capitalist labor legislation, liberalized trade, privatized all state-owned companies, swapped the foreign debt incurred by the former regime for global government bonds, partially privatized the state pension system, promoted transnational capital investments and enforced a monetary regime based on the automatic convertibility of Argentine pesos into dollars at a parity exchange level (Castagno $2010,119-176) .{ }^{33}$ In sum, according to the Menem administration the market would deliver all the material and symbolic goods that the government believed the state could no longer distribute, but in effect neoliberalism dramatically increased social inequality. As cultural critic Beatriz Sarlo describes in the early 1990s, with Menem in power "Argentina lives in the cultural climate of what is considered 'postmodernity' in the frame of a nation fractured and impoverished. Twenty hours of daily television, on fifty channels, and the public school without any symbolic or material resources" (Sarlo 1994, 7). This systemic social inequality rose throughout the 1990s and became politically unsustainable for the state. By the late 1990s unemployed reached eighteen percent and poverty thirty percent (Lozano 2005, 4).

In that context of inequality, the commercial media outlets circulated messages tempting consumers to join the so-called First World (e.g., Miami's shopping malls, European sports events) while — not in structural but in moral and individualistic terms - blaming corrupt politicians for Argentina's neoliberal economic woes (Castagno 2010, 226-231). These problems intensified in early 1999, when Brazil - a major Argentine trade partner - devalued its currency. Under these conditions, Argentines elected the center-right coalition ALIANZA, ${ }^{34}$ which promised to prosecute political corruption - a practice intimately linked to the privatization of state-owned companies (Verbitsky 1990). Despite this promise, the ensuing government only strove to preserve the neoliberal macroeconomic framework, increasing working-class austerity and honoring government bonds' payments. ${ }^{35}$ This assault provoked a reversal in citizens' expectations. In turn, workers and citizens resisted the rounds of neoliberal austerity. For example, the

${ }^{26}$ Law 23,696/89 (art. 65). The law 26,053/99 (art. 1) forbade public service companies to administer broadcasting licenses, but this restriction was removed through the legislation that authorizes foreign firms the same rights that their countries give to Argentine capital. See afterwards.

${ }^{27}$ Law 23,696/89 (art. 65)

${ }^{28}$ Decree $1062 / 98$.

${ }^{29}$ Decree $1771 / 91$ and $1005 / 99$

${ }^{30}$ National Constitution (art. 75).

${ }^{31}$ According to press information from La Nación on December 20, 2011 (http://www.lanacion.com.ar/1434200-grupoclarin-y-vila-manzano-dos-de-los-mayores-multimedios-del-pais, accessed on February 15, 2012), by 2011 Grupo Clarín controlled the 47 percent of the total cable television market, nine television channels (owned and represented), five cable television channels, the second most listened-to radio (Radio Mitre) and numerous radio licenses, the most widely read newspaper (Clarín) and other ten newspapers and magazines, 37 percent of the shares of the firm controlling paper commercialization for newspapers, and shares in top audiovisual companies. See also Grupo Clarín's website (http://www.grupoclarin.com/areas_y_empresas/clarin, accessed on February 15, 2012).

${ }^{32}$ See, for instance, the report of newspaper Perfil on April 5, 2009: "En guerra con Clarín, el gobierno decidió frenar la fusión de cables," (http://www.diarioperfil.com.ar/edimp/0353/articulo.php?art=13669\&ed=0353, accessed on January 15, 2012).

${ }^{33}$ Menem's government established an ad-hoc 'Euro': as the Euro replaced former national currencies in the European Union, in Argentina the dollar (i.e., the currency that works as universal monetary equivalent in Marxist terms) became a state tool with which to discipline the economy, pressuring labor to adapt to the competitive strength of the dollar in the global economy.

${ }^{34}$ Alianza para la Educación, la Salud y el Empleo (Coalition for Education, Health and Employment) formed by the traditional party UCR and the center-left coalition FREPASO.

${ }^{35}$ ALIANZA approved a labor law that removed collective bargaining; reduced state workers' wages; aimed to privatize trade unions' health funds; and swapped junk government bonds, passing them to national and global pensioners (Castagno 2010, 287-289). 
two confederations of trade unions carried out eight general strikes, the social movement of unemployed workers gained momentum, and in key districts blank votes won the parliamentary elections of $2001 .{ }^{36}$ In late 2001 citizens in major cities filled public squares, obligating President Fernando de la Rúa to resign. Citizens rejected the President and the main political parties under the motto: "They Must All Go!" (Solanas 2004; Pousadela 2008). Yet, despite those demonstrations, the traditional political parties remained, electing a new president through a parliamentary pact. In the name of the nation, President Eduardo Duhalde turned the slump into a capitalist exit: his government sharply devalued the currency and lowered wages, ${ }^{37}$ cleared big corporations' banking debts at the expense of citizens' saving accounts and repressed the protest of unemployed workers (Castagno 2010, 317-338). This moment of crisis in state authority ended with the election of President Néstor Kirchner in 2003.

\section{The Post-Neoliberal State and the Media}

"Only when relationships have so far developed and conflicts of interest have reached such an intensity that even the average eye can penetrate beyond appearances to what is really going on, does a conscious ideological apparatus in the full sense usually make its appearance."

Max Horkheimer, Notes on Science and the Crisis $(1989 / 1932,55)$

Despite its proponents' explicit disavowal of neoliberal policies and their professed national-popular political orientation, Kirchnerismo has sustained the long state capitalist project of embedding the economy in global capitalism and enforcing an unequal class structure. Firstly, in commodity production, currency devaluation and the hike in global commodity prices (agricultural goods, energy, mining) combined to intensify the export-led dimension of the Argentine economy and conquer new markets: between 2003 and 2010 exports rose from US\$29.9 billion to US\$68.1 billion, increased by the export of cars to Brazil, soy to Asia and mining products to the global market. Northern capital controls this backbone of capitalist reproduction (Chudnovsky 2001, 96). ${ }^{38}$ Secondly, the governments of Néstor Kirchner and Cristina Fernández de Kirchner reduced foreign debt as percentage of GDP and nationalized the private pension system, yet foreign debt as percentage of GDP is now near pre-slump levels while the new state pension fund has a vast amount of government bonds in its portfolio. ${ }^{39}$ In other words, Kirchnerismo has passed the debt burden along to pensioners, while it refuses to grant pensioners the 82 percent of the current wage corresponding to their former labor activities. Thirdly, Kirchnerismo reestablished collective bargaining, but the percentage of workers outside the formal labor market (and thus collective bargaining) remains, at its lowest estimate, thirty-four percent of the total working population. ${ }^{40}$ This is an important factor in explaining why the participation of wages in GDP has tended to remain stagnant since the 1970s (Graña and Kennedy 2008, 4), when the capitalist assault intensified. Next, Kirchnerismo claims to have reduced poverty to ten percent, but this figure is based on outdated statistics that establish in 1,423 pesos (US\$326) the monthly sum an average family of four needs to live. ${ }^{41}$ In short, the fact that Kirchnerismo keeps reproducing an unequal transnational class structure is revealed in Argentina's export of 70 billion dollars to Northern financial centers over the last four years (Damill and Frenkel 2009, 22; Cano 2011).

Yet Kirchnerismo has also contributed popular-democratic accretions to the pre-existing state formation. It annulled Menem's government decree that had pardoned former commanders for their crimes;

\footnotetext{
${ }^{36}$ In the cities of Buenos Aires and Santa Fe, blank ballot papers and spoiled ballot papers won the election. In Buenos Aires province, blank ballot papers and spoiled ballot papers came in second. In Córdoba, they ended third. Argentina has a presidential system of government with an Executive Branch, a bicameral legislature formed by the Senate and the Chamber of Deputies (Congreso Nacional), and a Judicial Branch. I use the term parliament to refer to that bicameral legislature.

${ }^{37}$ Currency devaluation meant that even four years after the crisis, average wages were eleven percent below their level in 2001 (Graña and Kennedy 2008, 65). Devaluation changes the relative prices in the economy. Wages (set in the national currency) deteriorate in relation to commodities exported abroad (set in dollars).

${ }^{38}$ As result of the neoliberal reform of the 1990s, multinational corporations went on to control about 99 percent of total automobile exports, 99 percent of total mining exports and 62.4 percent of total agricultural exports-vegetal oils and grains (Chudnovsky 2001, 96).

${ }^{39}$ Foreign debt is currently about 46.3 percent of GDP (Ministerio de Economía 2011). By 2001 the private pension system had about 76 percent of workers' pension funds in government bonds, which the state then defaulted on and finally swapped (Castagno 2010, 159-176). A decade later, the state pension fund has 57.8 percent of its funds invested in government bonds (ANSES 2011). More than thirty-five percent of those bonds are invested in pesos, while the unofficial inflation rate is three times the official one. This means that future pensions are being devalued. Indeed, the government did not use the state pension fund to raise the pensions of workers that had contributed to the private pension system, and so in practice appropriated those funds.

${ }^{40}$ Report from the Instituto Nacional de Estadísticas y Censos (National Institute of Statistics and Census, INDEC) on June, 2011 (http://www.argentina.ar/_es/economia-y-negocios/C8227-el-trabajo-en-negro-cayo-al-341-por-ciento.php, accessed on January 15, 2012).

${ }^{41}$ As newspaper La Nación informs on November 18, 2011( http://www.lanacion.com.ar/1424468-segun-la-iglesia-el-35de-los-habitantes-del-area-metropolitana-es-pobre, accessed on February 3, 2012), according to the conservative Catholic Church poverty in the greater metropolitan area of Buenos Aires is four times higher than what official statistics contend.
} 
implemented a minimum subsistence payment for children of unemployed families; legalized same-sex marriage; and partially democratized the media. These policies answered citizens and workers' demands to a degree. As an activist from the community radio La Posta phrased it during the parliamentary discussion of the media reform, "We believe that the challenges that democracies face in this conjuncture, and in our country since the crisis of 2001-2002, has to do with answering the demands of large social sectors to participate in the administration, control and implementation of public policies" (FARCO 2009, 42). ${ }^{42}$ My task is to evaluate the extent to which Cristina Fernández de Kirchner's media reform (Law 26,522) has grasped and addressed these popular-democratic demands to participate in the implementation and development of public policies.

At first glance these media reforms seem to have significantly addressed popular demand for participation. The new law (and the other progressive public policies of Kirchnerismo) has substantial consent from media activists, not-for-profit media organizations, community media, human rights organizations, trade unions and academics (Baranchuk and Usé 2011; Busso and Jaimes 2011). These civil society actors developed the progressive guidelines of Coalición para una Radiodifusión Democrática (Coalition for Democratic Broadcasting), which united those various sectors and pressured the Kirchnerismo government to change media legislation. ${ }^{43}$ The coalition was a social movement consonant with international movements of media activists that struggle to define the media as an institution of public interest, establish communications as a human right and democratize the media (International Commission 1980; Hackett and Zhao 2005). Regardless of whether this perspective may in fact be compatible with the capitalist system, its advocacy helps to change political perceptions, establish legal instruments for democratic emancipation and destabilize the dominion of commercial media. That is, the struggle to build a new public sphere seems important for what Gramsci refers as a long "war of position" for cultural and political emancipation (2000, 225-228). As Vicent Mosco argues, one way to employ the concept of the public sphere effectively is to define it "as a set of social processes that carry out democracy, namely advancing equality and the fullest possible participation in the complete range of economic, political, social, and cultural decision-making" $(2010,152)$. I argue the results obtained by the Coalición must be read in that tactical way: the media reform opens new horizons for democratic and socialist emancipation.

Thus, the advancement of the law on Audiovisual Communication Services is its definition of audiovisual services as activities of public interest through which it is expressed the human right to communicate. ${ }^{44}$ Indeed, the law stipulates the state must protect the right to information, participation and freedom of speech. It stresses that the goal of audiovisual services is the promotion of diversity, universal access and participation. Based on that voluntaristic perspective, the law nevertheless guarantees the right of not-for-profit media to enter the media sphere. Specifically, it requires the state to distribute broadcasting, cable television and digital platforms' licenses on equal terms among state media providers, commercial media providers and not-for-profit media providers: the latter are civil society institutions (foundations, civic associations, churches, trade unions) that provide media services to their communities. Further, the law automatically authorizes public universities, the Catholic Church and indigenous communities to administer audiovisual licenses. ${ }^{45}$

However, one important problem for developing that democratic agenda is that the law conflates public and state institutions, controlled by the federal government. In particular, despite including the participation of parliamentary political sectors and representatives from trade unions, public universities, indigenous communities and human rights organizations in debates over proposed legislative reform and in the new regulatory institutions, it is still the case that the Executive Power is in charge of implementing the law through the Autoridad Federal de Servicios de Comunicación Audiovisual (AFSCA, Federal Authority on Audiovisual Communication Services). ${ }^{46}$ The Executive Power and the dominant national political party nominate most of the representatives of AFSCA: three out of seven, without considering their probable influence in nominating two additional representatives through the votes of the representatives of the provincial governors - in Argentina the political party that wins the national presidential election normally wins most of the provincial elections and has majority in the parliament (figure 1). Similarly, the law does not establish any mechanism through which the administration of state media may

\footnotetext{
${ }^{42}$ FARCO is the Argentine Forum of Community Radios, it represents about eighty community radios and promotes social solidarity, democracy, public transparency, diversity and pluralism.

${ }^{43}$ The Coalition reunited more than three hundred organizations from civil society (e.g., community media, trade unions, human rights organizations, public universities).

${ }^{44}$ The law overstates its scope. It claims to be about the development of information society but it fundamentally applies to broadcasting, cable television and satellite television; since it defines that audiovisual communication services are based on a programming timetable (art. 4). It neither regulates the Internet nor telecommunications, though in one occasion it refers to broadcasting to "mobile receivers" (art. 4). Similarly, it does not give specifications on digital television platforms (Televisión Digital Abierta, Open Digital Television), a recent state initiative. It simply states that current regulations, universal access and participation must be respected when digital platforms are established (art. 93). The law is also overcharged with notes detailing Northern legislations.

${ }^{45}$ It is too early to evaluate whether these measures have translated into substantive change in the media sphere.

${ }^{46}$ Art. 7.
} 
become independent from the state - and more importantly, the federal government; ${ }^{47}$ the state company Radio y Televisión Argentina Sociedad del Estado (RTA S.E.) manages all the state's media and is mostly controlled by the Executive Power and the dominant national political party. ${ }^{48}$

$>$ AFSCA is the state body in charge of applying the legislation, elaborating technical norms and controlling monopolistic practices.

$>\quad$ The Executive Power nominates two officials to AFSCA; a parliamentary commission nominates three officials belonging to the three largest political sectors in the parliament; the Consejo Federal de Comunicación Audiovisual (CFCA, Federal Council on Audiovisual Communication Services) nominates two officials (one has to belong to a public university that offers a communication degree).

$>$ CFCA is constituted by the representatives of the provincial governments (23) and the government of Buenos Aires city; three representatives of the private media associations; three representatives of the associations of non-for-profit media producers; one representative of the state media; one representative of the broadcasting stations of public universities; three representatives of the trade unions within the media sector; one representative of human rights organizations; and one representative of all the indigenous ethnic groups.

$>$ CFCA advises and proposes policies to AFSCA.

$>$ The Executive Power can directly authorize (previous selection process) broadcasting licenses in cities with more than 500,000 inhabitants.

$>\quad$ The Defense of the Public office receives denounces from citizens.

Figure 1: Regulatory Institutions (art. 12-16, 19, 32)

Another crux of discussion is the regulation of licenses. As I mentioned, the new legislation basically limits previous neoliberal reforms by dividing in equal terms the broadcasting spectrum and audiovisual space for distributing licenses among the commercial media, the state and not-for-profit media. It also reduces from twenty-four to ten the number of licenses a single broadcaster can hold, forbids audiovisual providers from transferring licenses, establishes twenty-four as the number of licenses a cable television company can administer and impedes cable television companies from owning broadcasting television channels (figure 2). Moreover, the law mandates that cable television and satellite television companies deliver Latin American, state, provincial and local channels. ${ }^{49}$

$>\quad$ The audiovisual space is divided among state, commercial and not-for-profit audiovisual providers in equal terms (thirty-three percent of every audiovisual space for each sector of providers).

$>\quad$ Licenses cannot be transferred.

$>\quad$ The provider of audiovisual services by satellite (one license for the whole territory) cannot hold any other audiovisual license. One provider of audiovisual services cannot administer more than ten broadcasting licenses. One provider of paid audiovisual services utilizing cable networks cannot administer more than twenty-four licenses.

$>$ Any provider of audiovisual services cannot reach more than thirty-five percent of the national audience.

$>\quad$ In every locality one audiovisual provider cannot administer more than one AM radio, two FM radios, and one television or cable television license.

$>$ Cable television companies cannot deliver more than one cable television signal of their own.

$>\quad$ All national public universities will receive one radio and one television license.

$>\quad$ All state institutions and the Catholic Church have the right to receive licenses.

$>\quad$ Every indigenous ethnic group has the right to one radio and one television license in each locality it is based.

$>$ All city-states have the right to one FM radio license. Each province and Buenos Aires city has the right to one $\mathrm{AM}$ radio license, one $\mathrm{FM}$ radio license and one television license.

Figure 2: Administration of licenses (art. 2, 25, 29, 37, 38, 41, 45, 89)

Kirchnerismo thus claims the new law severely restricts media monopolies and increases diversity. Yet the peril is that the repetitive official discourse against media concentration would become akin to beating a dead horse. To put it differently, from a Marxist standpoint it is necessary to highlight that media concentration and centralization is a result of capitalist competition and of the tendency of the rate of profit to fall. Marx explains that as firms introduce more technology in production to produce more and

\footnotetext{
${ }^{47}$ In contrast, the Coalición por una Radiodifusión Democrática stated in its proposal that state media must be public $(2011,157)$.

${ }^{48}$ The institutional mechanism to nominate RTA S.E. directors is similar to the case of AFSCA (art. 119, 132).

49 For instance, after the law 26,522 cable television companies had to deliver the Venezuelan television channel Telesur, the state movie channel IncaaTV (Argentine films), and the state channel for children Paka Paka, all this expanded media diversity.
} 
cheaper commodities to compete on the market, ${ }^{50}$ less human labor is exploited per commodity and mass of commodities, so in relative terms profits tend to fall. In Marx's account surplus-value and profits are a direct result of the exploitation of human labor. ${ }^{51}$ In turn, to counteract this tendency, firms need to optimize the use of constant capital (fixed capital, technology), intensify the exploitation of labor and create new associations of production (Marx 1991/1894, 317-375). Briefly, while for bourgeois economics 'pure' competition is the antithesis of concentration, Marx demonstrates how the concentration and centralization of capital are dialectically related to market competition among firms (Shaikh 1991, 76; Fuchs, 381).

Thus, if media regulations are not carefully established they cannot restrict 'concentration', due to the need of media companies to accumulate capital. In this regard, the law is confusing: it is filled with references to the elimination of monopolies, but it also stipulates that AFSCA needs to promote competition and investment. ${ }^{52}$ Lawmakers did not consider the contradiction between media competition and concentration because they did not have any intention of altering the capitalist foundations of the media: the regulation of concentration is simply part of a discursive and institutional project of adding populardemocratic accretions to the existing system. In effect, the new law maintains twenty-four licenses for cable television providers, authorizes satellite television companies (currently the American multinational Direct TV) to provide services to the whole territory with only one license, keeps authorizing crossownership between press and media companies, forbids telephone companies to enter the media market but authorizes cable television companies (e.g., Telecentro) to provide telephone services, ${ }^{53}$ and ultimately allows any capitalist undertaking that the treaties on international investments signed by Argentina authorizes - even when the same law explicitly prohibits the foreign ownership of media companies in Argentina. ${ }^{54}$ As noted above, in Argentina international treaties have supremacy over national laws.

The case of cable television licenses mentioned above is interesting to consider closely. The law authorizes twenty-four licenses for cable television companies in different localities; but it does not define what those localities are. ${ }^{55}$ This signifies that cable television companies could exert political pressures to define those localities in their advantage. In this sense, a press declaration from Daniel Vila - the owner of the second largest cable television company, Grupo Uno - on the number of cable television licenses managed by his company is particularly revealing (De Santis 2012). Refusing the view that the company is administering more licenses than those authorized by the law, Vila sustains the issue was resolved with new administrative regulations. These regulations agglomerated all the licenses corresponding to the localities situated in the greater metropolitan area of Mendoza city, where Grupo Uno masters the cable television market. As result, Grupo Uno now administers the same audiovisual services than before the law 26,522 but with fewer licenses. The new law, then, has left judicial and administrative paths open for corporations. This is also seen in article 161, which gives one year for companies to adapt to the new legislation and make disinvestments if necessary. Grupo Clarín has rejected that stipulation through legal recourses that have stopped the implementation of the law.

Thus the probable scenario is that media concentration will ultimately depend on the desires of the Executive Power and the judiciary to favor certain media conglomerates at expense of others. This is evident if we consider the case of Grupo Clarín, which is currently required by Cristina Fernández de Kirchner's government to make disinvestments, while prior to the new law it was authorized by Kirchner's government to acquire the cable television company Multicanal and reach forty-seven percent of cable television consumers (Laboratorio de Industrias Culturales 2011). In sum, along with its partial democratization of the media, the spirit of Kirchnerismo would be to build state-commercial media associations. This is seen in article 153 on public policies, which establishes that the Executive Power "must adopt policies destined to promote the formation and development of national audiovisual conglomerates in all the formats and media platforms, facilitating the dialogue, cooperation and business organization among economic actors, public institutions, private institutions, and academic institutions, in benefit of competitiveness." 56 This state-capitalist convergence is resisted by a sector of not-for-profit media

\footnotetext{
${ }^{50}$ As I noted above, this increases the concentration and centralization of capital.

51 The rate of surplus-value refers to the proportion of unpaid labor that workers transfer to the capitalist class over the necessary labor time that workers spend reproducing their needs, and is paid as wages - variable capital (Marx $1990 / 1867,320-329$ ). The rate of profit is the relationship of surplus-value to total capital (variable and constant capital) over a cycle of capital reproduction (Marx 1991, 132-140).

${ }^{52}$ Art. 12 .

53 The original project of Kirchnerismo authorized telephone companies to enter the cable television market. It is unclear whether the government deleted this article in order to attract the positive vote of center-left deputies to the project or due to power issues involving the main telephone company Telefónica International, which currently controls about the ninety percent of the Argentine telephone market.

${ }^{54}$ Foreign capital cannot control more than thirty percent of the shares of any audiovisual company (art. 29), but this limitation is removed in case of international treaties on investments.

55 "The regulatory authority will determine the territorial and demographic limits of the licenses" (art. 45, c).

56 This desire to reconcile media diversity and businesses is certainly not just seen in Argentina. Even UNESCO's declaration on cultural diversity is ambiguous (2002). It establishes that cultural goods - as vectors of identity, values and mean-
} 
activists and producers. For example, AFSCA has recently opened a bidding process to grant licenses on the new state digital platform (Televisión Digital Abierta). However, not-for-profit media organizations assert they cannot afford the price of the bidding specifications to participate in the selection process and the monthly sum required by the state to operate audiovisual services in the newly digital platform (Faro TV et al. 2011). They claim that the new media policy has in reality "enlarged the state but not the communities": the only not-for-profit media organizations that can benefit from the newly digital platform are those belonging to powerful civil society institutions (e.g., some conservative trade unions) entangled with the state (CoorDeCAAP 2011). ${ }^{57}$

\section{Populism Revisited} tal."

"There are no contradictions between workers and capital, and between national and foreign capi-

National Deputy, A24 Televisión, 2011

For a Marxist approach is important to consider the theoretical implications we can draw from the case of Kirchnerismo and its media policy. My argument is that Kirchnerismo contributed populardemocratic accretions to the existing state formation by articulating demands for human rights, media democratization, collective bargaining and social security. This entailed a partial populist mobilization of citizens. As Ernesto Laclau argues, populism is a form of political construction characterized by the articulation and mobilization of popular demands against the institutional system that is not answering them. These demands are heterogeneous but they share mutual dissatisfaction with the institutional status quo (Laclau 2009, 97-103). According to Laclau, 'the people' of populism emerges when a plebs (the masses, the underprivileged) claims to be the whole community (populus), establishing a frontier in the political field against the supposed enemies of the people. The populus thus emerges as a political subject collectivizing or "hegemonizing" heterogeneous popular demands in a relation of equivalence (2009, 150-151). Crucially, the populus is not a pre-existing social group but the result of an act of nomination for which an affective leader who condenses the popular demands and mobilizes the populus against the previous institutional status quo is essential (Laclau 2009, 128-130). For instance, in Argentina Kirchner emerged as a leader that represented popular demands opposed to neoliberalism and to the residual elements of the dictatorial period. Yet, as Laclau maintains, populism as a form of political construction can appear in different political movements $(2009,29)$. In his early work it was thus important for Laclau to observe how populist constructions are ideologically articulated to the class projects of hegemonic political groups (Laclau 1978, 223). ${ }^{58}$ Laclau's late work on populism tends to deemphasize this class articulation, but I contend consideration of the latter is crucial in developing a theory of populism from a Marxist perspective.

In this light, I argue it is important to observe how Kirchnerismo articulated its populist logic to its class project, which as I considered previously as consisting in reproducing capitalist transnationalization. In other words, Kirchnerismo needs to resolve the contradiction between its populist construction and its capitalist reproductive role. Its proponents may seek this resolution by rhetorically exaggerating its break with the status quo. For example, Kirchnerismo defended its media legislation by saying it eliminated the media law of the dictatorship and Grupo Clarín's monopoly. However, sooner rather than later assuaging structural cracks with rhetoric proved impossible. Kirchnerismo has therefore needed to find an institutional-ideological arrangement to accommodate its populist discourse within its capitalist aims. In the media sphere such an arrangement has consisted in the promotion of national media content. For instance, as noted previously, the new media legislation promotes state-commercial conglomerates. It also requires audiovisual providers to broadcast a minimum of Argentine national content, with the objective of both strengthening the national media industry and increasing jobs in the audiovisual field (figure 3).

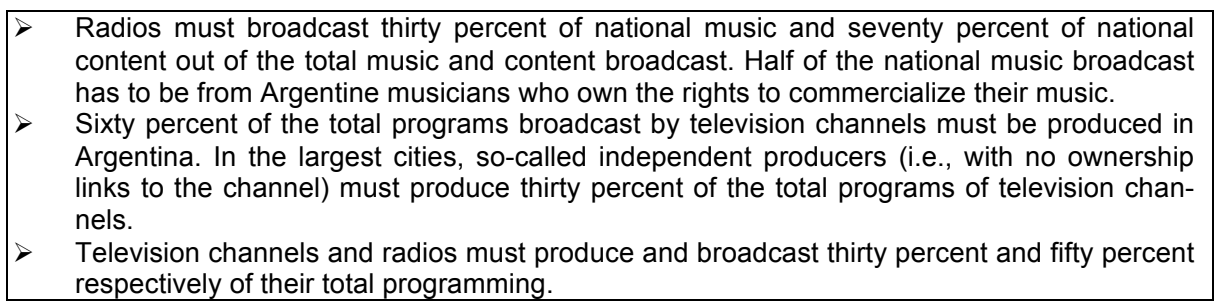

ing - must not be treated as mere commodities or consumer goods (art. 8). In other words, cultural goods are still partially seen as commodities.

${ }^{57}$ Coordinadora en Defensa de la Comunicación Comunitaria, Alternativa y Popular (Organization in Defense of Community, Alternative and Popular Communication). CoorDeCCAP unites about sixty not-for-profit media organizations.

${ }^{58}$ For instance, Perón linked his populism to the pre-existing project of national capitalism. 
Cable television and satellite television must deliver the channels belonging to the state the public universities, the provinces and Buenos Aires city.

$>\quad$ The principal television channels (reaching more than twenty percent of the population) are required to broadcast eight new national films or three produced television films per year.

\section{Figure 3: Audiovisual Contents (art. 65, 67)}

This promotion of the national media industry permits Kirchnerismo to ideologically adapt its populist discourse to the existing capitalist goals of the state ${ }^{59}$ Of course, this arrangement is progressive in the sense that it is a cultural force counteracting or at least parallel to the expansion of the North American and European commercial media. ${ }^{60}$ But at the same time it integrates content from state media producers, not-for-profit media and small commercial producers into the capitalist media industry. In this way, the project of a national culture industry helps to reproduce capitalism by adding use-values to the commercial media - a procedure that is common in contemporary culture (Crawford 1992, 15). As a consequence, and in contrast, it would be desirable for a practical socialist agenda to take advantage of the promotion of national content in order to press the state to implement truly public cable television channels or public digital platforms in which those cultural productions could be further developed democratically.

If this does not occur, as suggested, the menace of Kirchnerismo is that, pace its populism, it would paradoxically be implementing what Marx observes as Bonapartist, authoritarian exits to the structural antagonism between private property and working-class demands. ${ }^{61}$ In Marx's account, 'Bonapartism' appears as an authoritarian regime aimed at saving both the state and private property from socialist revolution, for which the state undermines bourgeois rights. While that kind of political regime is not analogous with Kirchnerismo - in 2011 for instance Cristina Fernández de Kirchner was re-elected with 54 percent of the votes - it is worth noting that some human rights organizations currently denounce coercive deviations in the national government. ${ }^{62}$ Nevertheless, I do want to employ the term Bonapartism in a comparable way when considering the establishment of complex and confusing state ad-hoc arrangements that, despite altering private property contracts, allow the state to continue reproducing both state hegemony and capitalist development. This kind of Bonapartist fuite en avant consists in creating what I term grey zones of capitalist activity and state authority. These grey zones are exempt from the democratic control of citizens.

A case in point in the media field is the television program Fútbol Para Todos (Football for Everybody); football is the most popular sport in Argentina and a marker of national identity. In 2009 Cristina Fernández de Kirchner's government suddenly agreed with the association of football clubs (AFA) to broadcast the football league in exchange for a significant sum, paid for by taxpayers. AFA broke its contract with TyC/Cablevisión and televised football events were put under state administration. As a result, the state television channel (TV Pública) now broadcasts free football media events to citizens, while previously TyC/Cablevisión only delivered them to its subscribers. Fútbol Para Todos has thus been an important populist-democratic move for Kirchnerismo, which claims to have recovered the goals that the private media had kidnapped - a pun on the military junta's crimes. And yet, behind the screen of the state television channel, a media company (La Corte), which competes to accumulate capital for entering the global media market, produces Fútbol Para Todos. ${ }^{63}$ This kind of opaque business-state association is visible in other areas: for instance, in the government's manipulation of official statistics on inflation - which benefits some financial retributions on government bonds at the expense of others, in the government's support of Northern mining companies extracting natural resources through openmining pits that are resisted by communities and ecological movements (Svampa and Antonelli 2009), in the facilities that corporations have had to export capital, in the subsidies that the state grants to inefficient railway companies, in the government's use of state pension funds to finance capital and the state treasury, in the government's directing state advertising toward media groups sharing an affinity with the

\footnotetext{
${ }^{59}$ It goes without saying that this national content is different from the nationalist-repressive culture industry of the military junta. For example, new state television channels Encuentro or IncaaTV broadcast documentaries on social protests or films that question the existing society.

${ }_{60}$ On the global expansion of the American and European media industry see, for instance, Herbert I. Schiller (1992/1969), Armand Mattelart and Seth Siegelaub (1979), and Lee Artz and Yahya R. Kamalipour (2003).

${ }^{61}$ In The Eighteenth Brumaire of Louis Bonaparte (1978/1852), Marx analyzes the rise to power of Louis Napoleón Bonaparte in France during 1848 and 1852. Marx observes that Bonaparte accumulated power in the Executive at expense of civil society and the political representatives of the bourgeoisie yet protected the material interests of the bourgeoisie in confusedly implementing capitalist development. See David Held (1991, 147-150).

${ }^{62}$ The most controversial issue is the government's newly approved legislation on terrorism. According to the Coordinadora Contra la Represión Policial e Institucional (CORREPI, Organization Against Police and Institutional Repression) the state could use the new legislation to repress social protests and labor strikes (CORREPI 2011).

${ }^{63}$ See, for example, the press report of El Cronista on January 13, 2012: "La productora preferida de la familia Kirchner desembarcó en Europa" (http://www.cronista.com/contenidos/2012/01/13/noticia 0037.html, accessed on February 1, 2012).
} 
official political line, or in the emergence of new media groups formed by private companies selling infrastructures to the state. ${ }^{64}$

\section{Conclusion}

As Alex Callinicos observes in his reading of Lenin and Daniel Bensaïd (Lenin 1965; Bensaïd 2004), for Marxism it is crucial to consider the specificity of the political field as a play of transfigured powers, through which the totality of social antagonisms, contradictions and struggles are translated into new languages, displaced, condensed or revealed by slips of the tongue (Callinicos 2012). Marx refers to that political practice when, questioning state power, he mocks the self-deceiving costumes with which politicians wish to conceal from their own view the limitations of the contents of their practices $(1978 / 1852,598)$. Argentina is not an exemption: from time to time state actors change and the drama varies according to the political repertoires the state seems cyclically to repeat - nationalist authoritarianism, economic liberalism and populism. My argument is that those ideological forms are destined to conceal the central structural contradiction of the state as an institution that must represent the general and national interests of citizens while reproducing a transnational capitalist process that - centered on the global North - increases misery in Argentina and therefore the resistance of citizens and workers to the state and capital. This is rendered all the more evident in the periods that Gramsci terms organic crises, as in the 1970s and partially in the early 2000s. In this sense, Kirchnerismo has been successful until the present in countering the crisis in state hegemony that erupted in 2001-2002. This dialectic approach to the state is complementary to Marxist works that consider the subjective connections of the political cadres to the dominant economic class (Miliband 1969), or the structural role of the state in organizing capitalist reproduction (Poulantzas 1969; 1973) - a perspective I also employed.

Further, considering the state ideological forms mentioned above, I argue the media sphere is a basal field through which the state aims to cloak its central contradiction. This field is an arena of political struggle, except when dictatorial regimes completely substitute coercion for hegemony. That is, I emphasize that political regimes and governments in Argentina have attempted to deny, conceal or displace in different ways the social antagonisms connected to the capitalist crises and political convulsions of the 1970s and the late 1990s. As I demonstrated, the nationalist-authoritarian media regulations established by the military dictatorship, the neoliberal administration of the media by Menem's government and the idiosyncratic populist-capitalist project of Kirchnerismo are regulatory and ideologically distinct. I believe this approach allows us to avoid establishing mechanistic relationships between class domination, political life and media transformations. Indeed, it entails observing how every state ideological form is contradictory in particular ways: the dictatorship restrained capital forces in the media while repressing dissent to favor capitalist interests; Menem's government opened the way to mass dissatisfaction when its market allures of wealth were not translated into the daily-life of workers; and Kirchnerismo could see its own regulations evaporate if the popular-democratic demands it partially addressed surpass the letter of its media reform, its maneuvers to accommodate workers to transnational capital and its dubious, grey zones of business activities and state authority.

\section{References}

Althusser, Louis. 2001/1970. Ideology and Ideological State Apparatus: Notes for an Investigation. In Lenin and Philosophy and Other Essays, edited by Louis Althusser, 85-126. New York: Monthly Review Press.

ANSES. 2011. Fondo de Garantía de Sustentabilidad del Sistema Integrado Previsional Argentino, Informe Mensual Octubre. Buenos Aires: ANSES. Accessed February 10, 2012.

http://www.anses.gob.ar/FGS/politicastransparencia/archivos/informes/Boletin_FGS 11 2011.pdf

Artz, Lee and Yahya R. Kamalipour, eds. 2003. The Globalization of Corporate Media Hegemony. Albany: State University of New York Press.

Artz, Lee, Macek, Steve, and Dana L. Cloud, eds. 2006. Marxism and Communication Studies: The Point is to Change It. New York: Peter Lang.

Baranchuk, Mariana, and Javier Rodríguez Usé, eds. 2011. Ley 26.522: Hacia un Nuevo Paradigma en Comunicación Audiovisual. Buenos Aires: AFSCA and Universidad Nacional de Lomas de Zamora.

Bensaïd, Daniel. 2004. Une Lente Impatience. Paris: Stock.

Busso, Néstor, and Diego Jaimes, eds. 2011. La Cocina de la Ley: El Proceso de Incidencia en la Elaboración de la Ley de Servicios de Comunicación Audiovisual en Argentina. Buenos Aires: FARCO.

Calcagno, Alfredo Eric. 1988. La Perversa Deuda. Buenos Aires: Legasa.

\footnotetext{
${ }^{64}$ On the government's manipulation of state statistics see the declaration from the circumspect group of public university economists Plan Fénix on the right to information (Plan Fénix 2012). On the increase of subsidies to railway companies see Mario Damill and Roberto Frenkel $(2009,64)$. On the unequal distribution of governmental advertising among media groups see, for instance, the following information from newspaper Perfil on September 5, 2010: "Pauta oficial: aumenta la brecha entre medios oficialistas y críticos" (http://www.diarioperfil.com.ar/edimp/0501/articulo.php?art=24047\&ed=0501, accessed on January 15, 2012). This report is based on official information. One provider of state infrastructures participating in the media sphere is the firm Electroingeniería.
} 
Callinicos, Alex. 2012. The Crisis Wears On. International Socialism: A Quarterly Journal of Socialist Theory (133). Accessed February 1, 2012. http://www.isj.org.uk/index.php4?id=773\&issue=133

Cano, Fernando. 2011. Dudas Argentinas. El País, October 30. Accessed February 27, 2012. http://elpais.com/diario/2011/10/30/negocio/1319979149_850215.html

Castagno, Pablo Andrés. 2010. "The State Crisis in Argentina: Global Fantasies and National Containment." PhD diss. George Mason University.

Castells, Manuel. 2000. The Rise of the Network Society. Oxford: Blackwell.

CEPAL. 2002. La Inversión Extranjera en América Latina y el Caribe. Santiago de Chile: Naciones Unidas.

Chudnovsky, Daniel, and Andrés López. 2001. La Transnacionalización de la Economía Argentina. Buenos Aires: EUDEBA/CENIT.

Coalición por una Radiodifusión Democrática. 2011. 21 Puntos Básicos por el Derecho a la Comunicación. In La Cocina de la Ley: El Proceso de Incidencia en la Elaboración de la Ley de Servicios de Comunicación Audiovisual en Argentina, edited by Néstor Busso and Diego Jaimes, 155-161. Buenos Aires: FARCO.

CONADEP. 2003. Nunca Más: Informe de la Comisión Nacional sobre la Desaparición de Personas. Buenos Aires: CONADEP.

COORDECAAP. 2011. Comunicado de Prensa ¿Qué Está Concursando AFSCA? Buenos Aires: CoorDeCAAP. Accessed January 15, 2012. http://argentina.indymedia.org/news/2011/11/799065.php

CORREPI. 2011. Comunicado de Prensa: Leyes Antiterroristas. Buenos Aires: CORREPI. Accessed January 15, 2012. http://correpi.lahaine.org/?p=1103

Crawford, Margaret. 1992. The World in a Shopping Mall. In Variations on a Theme Park: The New American City and the End of Public Space, edited by Michael Sorkin, 3-30. New York: Hill and Wang.

Damill, Mario and Roberto Frenkel. 2009. Las Políticas Macroeconómicas en la Evolución Reciente de la Economía Argentina. Seminarios de Economía № 112. Banco Central de la República Argentina. Accessed February 28, 2012. http://www.bcra.gov.ar/pdfs/investigaciones/PaperFrenkel Damill.pdf

De Santis, Juan Pablo. 2012. Daniel Vila: Los Medios Mensajeros de la Ideología Tienen Una Pauta Importante. La Nación, February 2. Accessed February 7, 2012. http://www.lanacion.com.ar/1444898-daniel-vila-queremos-un-desguace-decablevision-y-multicanal

Duménil, Gérard, and Dominique Lévy. 2004. Capital Resurgent: Roots of the Neoliberal Revolution. Cambridge: Harvard University Press.

FARCO. 2009. Nueva Ley de Medios Audiovisuales: Desafíos Para los Medios Comunitarios y Populares. Buenos Aires: FARCO.

Faro TV et al. 2011. Carta a AFSCA: Televisión Digital ¿Para quién es la democratización? Accessed February 10, 2012. http://argentina.indymedia.org/news/2011/07/788002.php

Fuchs, Christian. 2009. Some Theoretical Foundations of Critical Media Studies: Karl Marx and the Media. International Journal of Communication 3: 369-402.

Fuchs, Christian. 2011. Foundations of Critical Media and Information Studies. New York: Routledge.

Garnham, Nicholas. 1979. Contribution to a Political Economy of Mass Communication. Media, Culture \& Society 1 (2): 122146.

Gramsci, Antonio. 2000. The Antonio Gramsci Reader: Selected Writings 1916-1935. New York: New York University Press.

Graña, Juan M., and Damián Kennedy. 2008. Salario Real, Costo Laboral y Productividad, Argentina 1947-2006. Documentos de Trabajo 12. Buenos Aires: Centro de Estudios sobre Población, Empleo y Desarrollo. Accessed January 10, 2012. http://www.econ.uba.ar/www/institutos/economia/Ceped/publicaciones/dts/DT\%2012\%20\%20Grana\%20Kennedy.pdf

Hackett, Robert A. and Yuezhi Zhao, eds. 2005. Democratizing Global Media: One World, Many Struggles. Lanham: Rowman and Littlefield.

Harvey, David. 1991. The Condition of Postmodernity: An Inquiry into the Origins of Cultural Change. Oxford: Blackwell.

Held, David. 1991. Modelos de Democracia. Madrid: Alianza Editorial.

International Commission for the Study of Communication Problems. 1980. Many Voices, One World: Towards a New More Just and More Efficient World Information and Communication Order. London: Kogan Page.

Horkheimer, Max. 1989/1932. Notes on Science and the Crisis. In Critical Theory and Society: A Reader, edited by Stephen E. Bronner and Douglas M. Kellner, 52-57. New York: Routledge.

Laboratorio de Industrias Culturales. 2011. Una Aproximación a las Industrias Culturales. Buenos Aires: Secretaría de Cultura. Accessed January 15, 2012. http://lic.cultura.gov.ar./investigaciones/industrias/index.php

Laclau, Ernesto. 1978. Politica e Ideología en la Teoría Marxista: Capitalismo, Fascismo, Populismo. Madrid: Siglo XX Editores. English version: Laclau, Ernesto. 1977/2012. Politics and Ideology in Marxist Theory: Capitalism, Fascism, Populism. London: Verso.

Laclau, Ernesto. 2009. La Razón Populista. Buenos Aires: Fondo de Cultura Económica. English version: Laclau, Ernesto. 2005. On Populist Reason. London: Verso.

Lenin, Vladimir I. 1965. Collected Works, Volume 32. Moscow: Foreign Languages Publishing House.

Lozano, Claudio. 2005. Los Problemas de la Distribución del Ingreso y el Crecimiento en la Argentina Actual. Buenos Aires: Instituto de Estudios y Formación de la Central de Trabajadores Argentinos.

Lukács, Georg. 2000/1923. History and Class Consciousness: Studies in Marxist Dialectics. Cambridge: The MIT Press.

Marx, Karl. 1978/1852. The Eighteenth Brumaire of Louis Bonaparte. In The Marx-Engels Reader, edited by Robert C. Tucker, 594-617. New York: W. W. Norton \& Company.

Marx, Karl. 1978/1867. Capital, Volume One. In The Marx-Engels Reader, edited by Robert C. Tucker, 294-438. New York: W. W. Norton \& Company.

Marx, Karl. 1978. Crisis Theory. In The Marx-Engels Reader, edited by Robert C. Tucker, 443-465. New York: W. W. Norton \& Company.

Marx, Karl. 1990/1867. Capital: A Critique of Political Economy: Volume I. London: Penguin Books.

Marx, Karl. 1991/1894. Capital Volume III. London: Penguin Books.

Marx, Karl. 1992/1885. Capital Volume II. London: Penguin Books. 
Marx, Karl. 1998/1845. Theses on Feuerbach. In The German Ideology, edited by Karl Marx and Friedrich Engels, 572-574. Amherst: Prometheus.

Marx, Karl, and Friedrich Engels. 1978/1848. Manifesto of the Communist Party. In The Marx-Engels Reader, edited by Robert C. Tucker, 469-500. New York: W. W. Norton \& Company.

Marx, Karl, and Friedrich Engels. 1998/1846. The German Ideology. Amherst: Prometheus.

Mattelart, Armand and Seth Siegelaub, eds. 1979. Communication and Class Struggle. Vol. 1: Capitalism, Imperialism. New York: International General.

McChesney, Robert W. 2007. Communication Revolution: Critical Junctures and the Future of Media. New York: The New Press.

Miliband, Ralph. 1969. The State in Capitalist Society. New York: Basic Books.

Ministerio de Economía. 2011. Deuda Pública del Estado Argentino. Buenos Aires: MECON. Accessed February 24, 2012. http://www.mecon.gov.ar/finanzas/sfinan/documentos/informe deuda publica 31-03-11 espanol.pdf

Mosco, Vincent. 2010. The Political Economy of Communication. London: Sage Publications.

Murdock, Graham and Peter Golding. 1973. For a Political Economy of Mass Communications. The Socialist Register 10: 205-234.

O’Donnell, Guillermo. 1984. Democracia en la Argentina Micro y Macro. In Proceso, Crisis y Transición Democrática, edited by Oscar Oszlack, 13-30. Buenos Aires: Centro Editor de América Latina.

O'Donnell, Guillermo. 1988. Bureaucratic Authoritarianism: Argentina, 1966-1973, in Comparative Perspective. Berkeley: University of California Press.

Oficina de la CEPAL en Buenos Aires. 2010. Evolución de la Desocupación en Algunas Áreas Urbanas. Buenos Aires: CEPAL. Accessed January 21, 2012. http://www.cepal.org/cgibin/getprod.asp?xml=/argentina/noticias/paginas/9/9839/P9839.xml\&xsl=/argentina/tpl/p18f.xs|\&base=/argentina/tpl/topbottom.xsl

Plan Fénix. 2012. Derecho a la Información. Página/12, February 14. Accessed February 14, 2012. http://www.pagina12.com.ar/diario/economia/2-187536-2012-02-14.html

Portantiero, Juan Carlos. 1974. Dominant Classes and Political Crisis in Argentina Today. Latin American Perspectives 1 (3): $93-120$.

Portantiero, Juan Carlos. 1977. Economía y Política en la Crisis Argentina: 1958-1973. Revista Mexicana de Sociología 39 (2): 531-565

Poulantzas, Nicos. 1969. The Problem of the Capitalist State. New Left Review (58): 67-78.

Poulantzas, Nicos. 1973. Political Power and Social Classes. London: New Left Books.

Pousadela, Inés M. 2008. Participation Vs. Representation? The Experience of the Neighborhood Assemblies of Buenos Aires. In Democratic Innovation in the South: Participation and Representation in Asia, Africa and Latin America, edited by Ciska Raventós, 71-122. Buenos Aires: Consejo Latinoamericano de Ciencias Sociales.

Rapoport, Mario. 2003. Historia Económica, Politica, y Social de Argentina. Buenos Aires: Ediciones Macchi.

Sarlo, Beatriz. 1994. Escenas de la Vida Postmoderna: Intelectuales, Arte, y Videocultura en la Argentina. Buenos Aires: Ariel.

Schiller, Herbert I. 1992/1969. Mass Communication and American Empire. Boston: Beacon Press.

Shaikh, Anwar. 1991. Centralization and Concentration of Capital. In A Dictionary of Marxist Thought, edited by Tom Bottomore. 76-77. Oxford: Blackwell Publishing.

Smith, Paul. 1997. Millennial Dreams: Contemporary Culture and Capital in the North. London: Verso.

Smythe, Dallas W. 1977. Communications: Blindspot of Western Marxism. Canadian Journal of Political and Social Theory 1 (3): $1-27$

Solanas, Fernando. 2004. Memoria del Saqueo. Directed by Fernando Solanas. Buenos Aires: Cinesur S.A., ADR Productions, Thelma Film AG.

Sourrouille, Juan Vital et al. 1985. Transnacionalización y Política Económica en la Argentina. Buenos Aires: CET.

Svampa, Maristella, and Mirta A. Antonelli, eds. 2009. Minería Transnacional, Narrativas del Desarrollo y Resistencias Sociales. Buenos Aires: Biblos.

UNESCO. 2002. Declaration Universelle de L'unesco sur la Diversite Culturelle. Paris: UNESCO.

Wayne, Mike. 2003. Marxism and Media Studies: Key Concepts and Contemporary Trends. London: Pluto Press.

\section{About the Author}

Pablo Castagno

is professor of political science at Universidad Nacional de La Matanza's Departamento de Derecho y Ciencia Política, Argentina. He received a PhD in Cultural Studies from George Mason University. His doctoral dissertation is titled "The State Crisis in Argentina: Global Fantasies and National Containment" and his publications on culture and media include the essay From Provinces to National Television: Celebrity Culture and Collective Recognition in the New Spain, in Mediations 23 (2), Spring 2008. He is currently working on a comparative study of the political manifestations of the global capitalist crisis in Southern Europe and South America. 